\title{
Real-Time Observations of a Coastal Upwelling Event Using Innovative Technologies
}

\author{
Jeffrey D. Paduan, Steven R. Ramp, and Leslie K. Rosenfeld \\ Department of Oceanography, Code OC/Pd, Naval Postgraduate School \\ Monterey, CA 93943 \\ phone: (831) 656-3350; fax: (831) 656-2712; email: paduan@nps.navy.mil \\ Document Numbers: N0001401WR20234 and N0001401WR20317 \\ http://www.oc.nps.navy.mil/ icon
}

\section{LONG-TERM GOALS}

The long term goals of this project are to develop a measuring capability for tracking and forecasting the development and decay of coastal upwelling circulations. A suite of real-time, remotely sensing instruments will input to a 3-D, data assimilating numerical model, which will support both circulation and ecosystem (e.g., bioluminescence potential) predictions.

\section{OBJECTIVES}

The objectives of this program are to demonstrate the utility of aircraft-derived sea surface temperature (SST) maps, together with HF radar-derived surface velocity maps, in tracking coastal upwelling fronts. These data are useful in guiding at-sea measurements and in constraining numerical circulation models. Additional objectives include demonstration of real-time acoustic telemetry of velocity profiles from a bottom-mounted ADCP, which provides critical subsurface data.

\section{APPROACH}

The approach taken has been to extend the unique suite of oceanographic and atmospheric sensors in and around Monterey Bay by flying additional sensors onboard a small airplane, and by deploying a newly developed acoustic telemetry system with an ADCP in a trawl resistant bottom mount (TRBM), during a period when the Office of Naval Research (ONR) and the Monterey Bay Aquarium Research Institute (MBARI) were sponsoring a multi-ship field program. The extended measurements complemented a three-site High Frequency (HF) radar network and three deep-ocean moorings already in place around Monterey Bay. A fourth mooring, the NPS Flux Buoy, was deployed within Monterey Bay during the course of the intensive field measurements, which took place in August 2000. An extensive modeling effort led by I. Shulman of the Univ. of S. Mississippi has taken place in parallel with these data-based efforts.

\section{WORK COMPLETED}

The field measurements were successfully completed in August 2000. Data analysis and preliminary data assimilation tests have been conducted in the ensuing year. The field effort was highly successful in each of the four areas targeted during the August campaign: 1) repeated aerial SST and wind mapping, 2) real-time acoustic telemetry of bottom-mounted ADCP data, 3) real-time surface velocity mapping from multiple HF radar sites, and 4) enhanced moored observations of surface winds. 


\section{Report Documentation Page}

Form Approved

OMB No. 0704-0188

Public reporting burden for the collection of information is estimated to average 1 hour per response, including the time for reviewing instructions, searching existing data sources, gathering and maintaining the data needed, and completing and reviewing the collection of information. Send comments regarding this burden estimate or any other aspect of this collection of information,

including suggestions for reducing this burden, to Washington Headquarters Services, Directorate for Information Operations and Reports, 1215 Jefferson Davis Highway, Suite 1204, Arlington

VA 22202-4302. Respondents should be aware that notwithstanding any other provision of law, no person shall be subject to a penalty for failing to comply with a collection of information if it

does not display a currently valid OMB control number.

\begin{tabular}{|c|c|c|}
\hline $\begin{array}{l}\text { 1. REPORT DATE } \\
\text { 30 SEP } 2002\end{array}$ & 2. REPORT TYPE & $\begin{array}{l}\text { 3. DATES COVERED } \\
\mathbf{0 0 - 0 0 - 2 0 0 2} \text { to 00-00-2002 }\end{array}$ \\
\hline \multirow{3}{*}{\multicolumn{2}{|c|}{$\begin{array}{l}\text { 4. TITLE AND SUBTITLE } \\
\text { Real-Time Observations of a Coastal Upwelling Event Using Innovative } \\
\text { Technologies }\end{array}$}} & 5a. CONTRACT NUMBER \\
\hline & & 5b. GRANT NUMBER \\
\hline & & 5c. PROGRAM ELEMENT NUMBER \\
\hline \multirow{3}{*}{\multicolumn{2}{|c|}{ 6. AUTHOR(S) }} & 5d. PROJECT NUMBER \\
\hline & & 5e. TASK NUMBER \\
\hline & & 5f. WORK UNIT NUMBER \\
\hline \multicolumn{2}{|c|}{$\begin{array}{l}\text { 7. PERFORMING ORGANIZATION NAME(S) AND ADDRESS(ES) } \\
\text { Department of Oceanography, Code OC/Pd,Naval Postgraduate } \\
\text { School,Monterey,,CA, } 93943\end{array}$} & $\begin{array}{l}\text { 8. PERFORMING ORGANIZATION } \\
\text { REPORT NUMBER }\end{array}$ \\
\hline \multirow{2}{*}{\multicolumn{2}{|c|}{ 9. SPONSORING/MONITORING AGENCY NAME(S) AND ADDRESS(ES) }} & 10. SPONSOR/MONITOR'S ACRONYM(S) \\
\hline & & $\begin{array}{l}\text { 11. SPONSOR/MONITOR'S REPORT } \\
\text { NUMBER(S) }\end{array}$ \\
\hline
\end{tabular}

12. DISTRIBUTION/AVAILABILITY STATEMENT

Approved for public release; distribution unlimited

13. SUPPLEMENTARY NOTES

14. ABSTRACT

The long term goals of this project are to develop a measuring capability for tracking and forecasting the development and decay of coastal upwelling circulations. A suite of real-time, remotely sensing instruments will input to a 3-D, data assimilating numerical model, which will support both circulation and ecosystem (e.g., bioluminescence potential) predictions.

15. SUBJECT TERMS

16. SECURITY CLASSIFICATION OF:

\begin{tabular}{c|c|c|c|c|c|}
$\begin{array}{c}\text { a. REPORT } \\
\text { unclassified }\end{array}$ & $\begin{array}{c}\text { b. ABSTRACT } \\
\text { unclassified }\end{array}$ & $\begin{array}{c}\text { ABSTRACT } \\
\text { unclassified }\end{array}$ & $\begin{array}{c}\text { Same } \text { as } \\
\text { Report (SAR) }\end{array}$ & $\mathbf{6}$ & RESPONSIBLE PERSON \\
& & &
\end{tabular}


Because these data built on the observations in place for the Innovative Coastal-Ocean Observing Network (ICON) project, the focus was on the aircraft- and TRBM-based data. Photographs of the support aircraft, Flux Buoy, and the TRBM are shown in Figure 1.

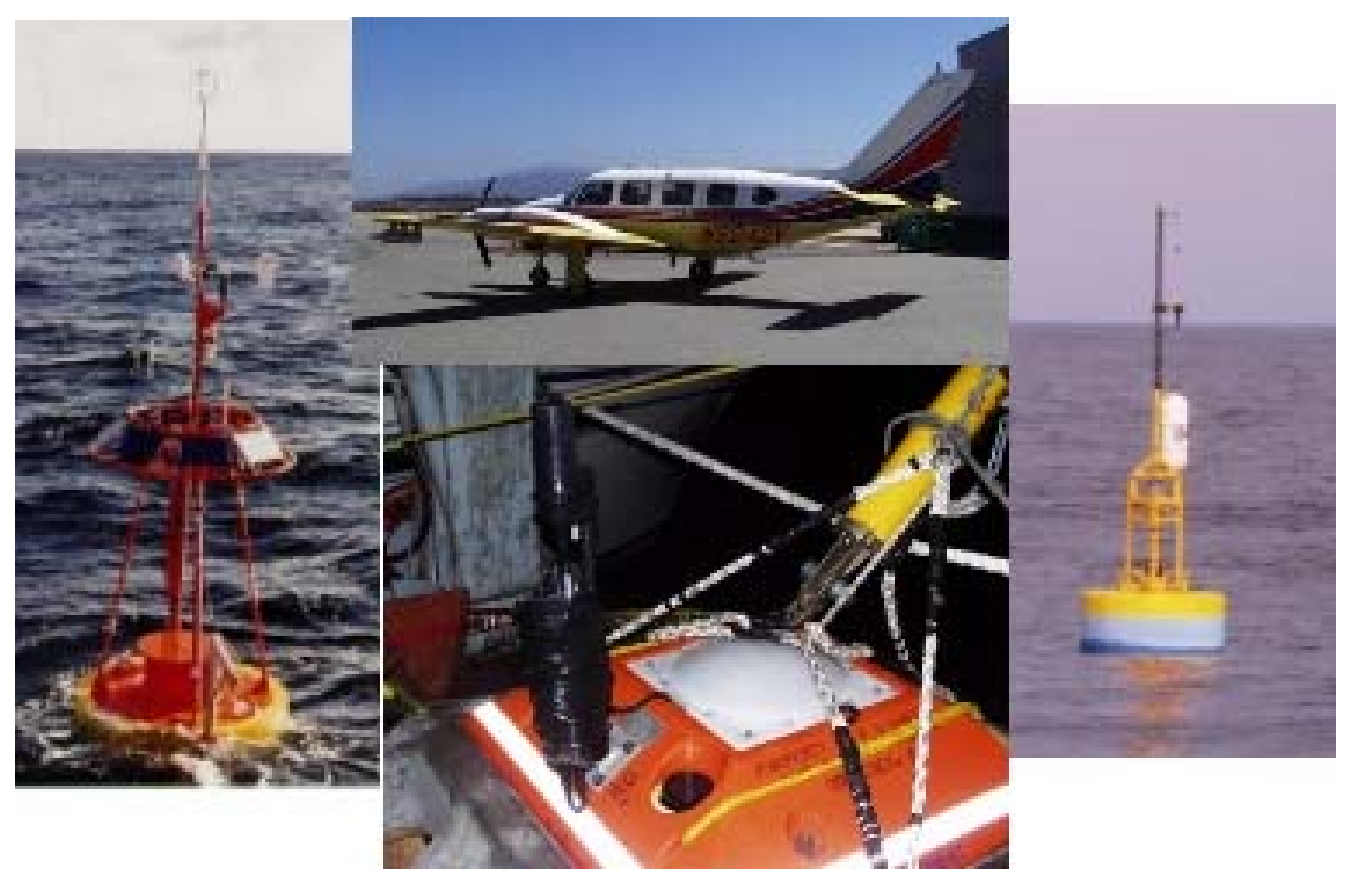

Figure 1. Photographs showing (clockwise from left) NPS Flux Buoy, twin-engine Navajo aircraft operated by SPAWAR and Gibbs Flight Center, Radio and acoustic telemetry mooring, and TRBM with ADCP and acoustic modem.

Thirteen aircraft surveys of Monterey Bay were conducted during the period 17-31 August 2000 (see: http://www.oc.nps.navy.mil/ icon/collaborations/muse_flights ). Velocity profiles over a $90 \mathrm{~m}$ water column in the northern portion of Monterey Bay were also obtained from an ADCP with acoustic telemetry capabilities during that period, while the NPS Flux Buoy was deployed in the eastern portion of the Bay. The aerial surveys provide an unprecedented time history of SST and winds during the period, which illustrate a complete cycle from strong upwelling circulation to onshore migration during relaxation/downwelling wind conditions. The aircraft data were collected from an altitude of $130 \mathrm{~m}$, which was below a thick status layer on most occasions. For comparison, only one useable SST map was obtained during the two-week flight period from satellite-based sensors.

\section{RESULTS}

The results of these measurements have served to show clearly the utility of low-altitude aircraft measurements over the coastal ocean. Dramatic temporal evolution of mesoscale ocean and atmosphere features were documented over a two week period when only one clear satellite image was available due to cloud cover. A clear example is shown in the sequence of images and surface data that were collected during an upwelling wind relaxation event between 27-29 August 2000 (Figure 2). 

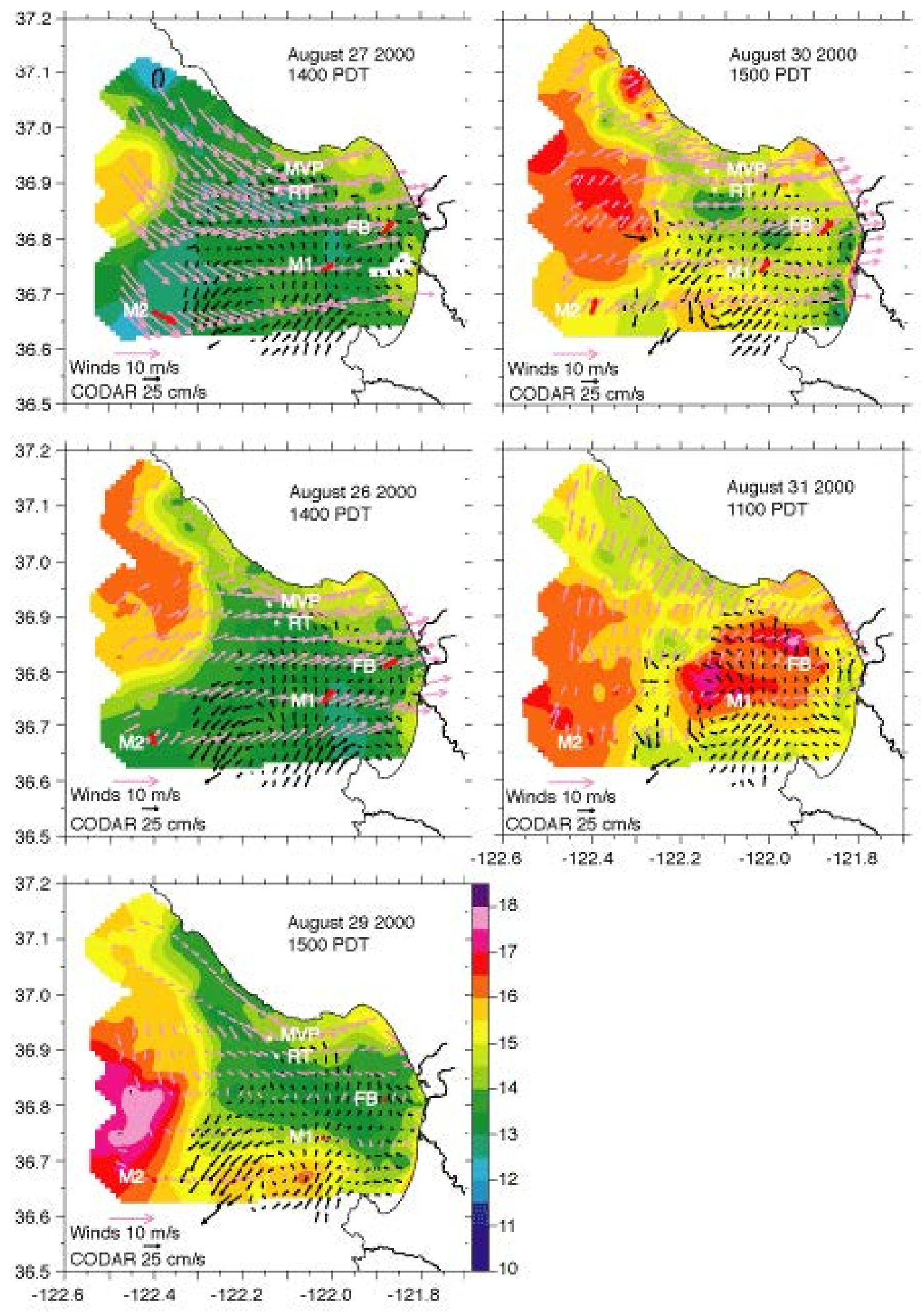

Figure 2. SST, HF radar-derived surface currents (black vectors), and wind at $130 \mathrm{~m}$ (pink vectors) on five days from 27 October to 31 October 2000. Surface wind vectors at MBARI( M1 and M2) and NPS (FB) moorings are also shown (red vectors). 
Along with upwelling-related mesoscale ocean features, the coastal region around Monterey Bay exhibits significant wind variations on small scales $(\sim 10 \mathrm{~km})$. Sheltering within Monterey Bay and the general effect of supercritical flow around headlands (Dorman et al., 1999; 2000) leads to very large and persistent positive wind stress curl in the north of Monterey Bay and south of Pt Sur (Figure 3).

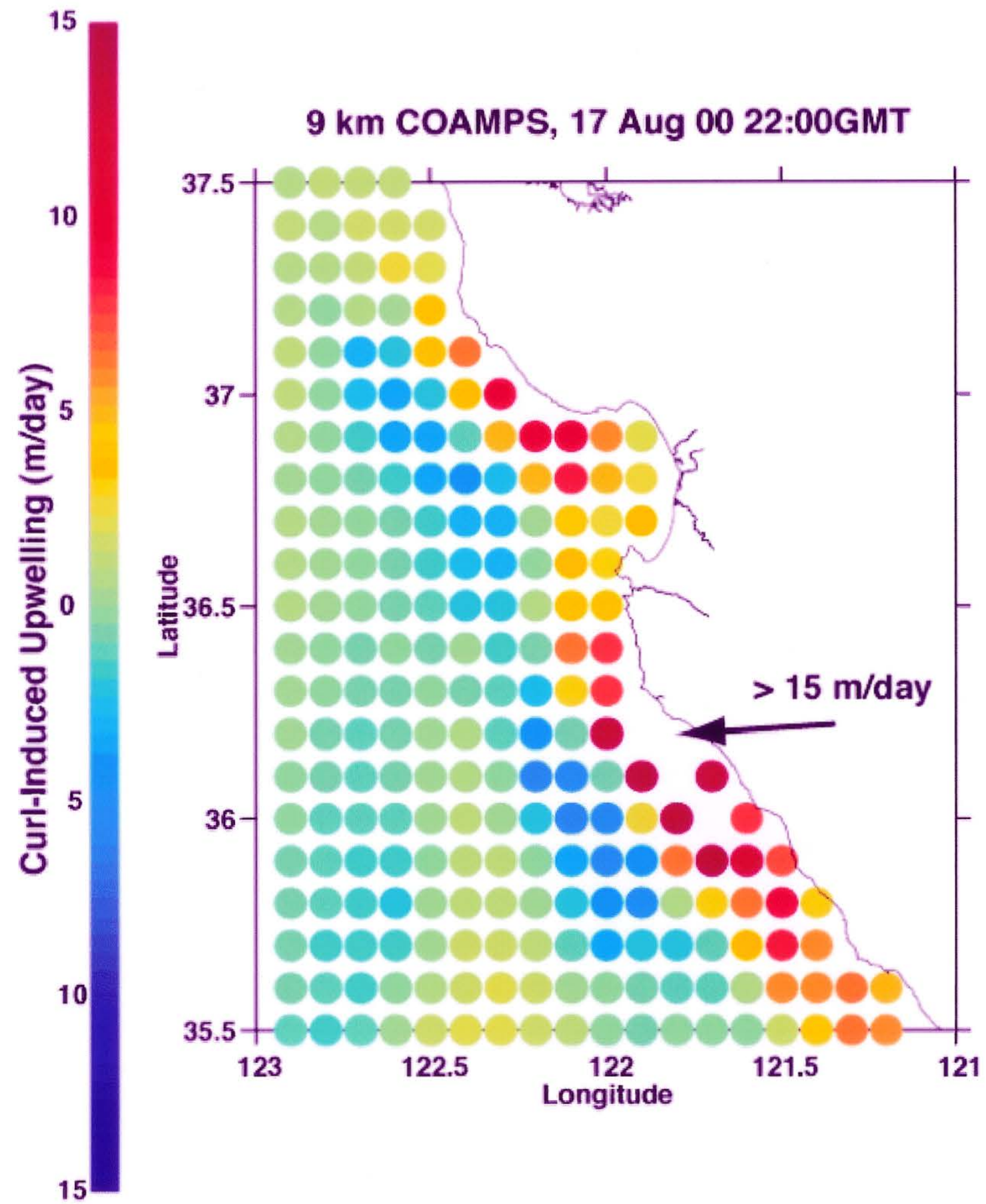

Figure 3. Hourly map of wind stress curl around Monterey Bay from $9 \mathrm{Km}$ COAMPS reanalysis product run by NRL Monterey. Patterns persist for weekly and monthly averages, which has highimpact implications for ocean circulation and the accompanying biological response. 


\section{IMPACT/APPLICATIONS}

The likely impacts of these observations will be the increased use of coastal SST and wind mapping with small aircraft and increased use of acoustic telemetry. Refinement and adoption of highresolution, non-hydrostatic atmospheric circulation models as input to coastal oceanography and monitoring is also a high-impact, likely application.

\section{TRANSITIONS}

The transition opportunities are in the area of rapid environmental assessment (REA) with increased use of aircraft, acoustic telemetry, and HF radar. These advances will also directly impact circulation models making them better-equipped to produce nowcasts and forecasts in the coastal ocean.

\section{RELATED PROJECTS}

This project is closely related to ONR program N00014-97-1-0171 (Shulman) and the NOPP/ICON program: N00014-98WR-30170, N00014-99WR-30118, N00014-00WR-20160, and N00014-02WR20086. The August 2000 field program coincided with the ONR Autonoumous Ocean Sampling Network (AOSN) program and the MBARI MUSE program. This project will be followed by aircraftbased coastal ocean measurements in the AOSN-II program N0001402WR20393.

\section{REFERENCES}

Dorman, C.E., D.P. Rogers, W. Nuss, W.T. Thompson, 1999: Adjustment of the summer marine boundary layer around Point Sur, California. Monthly Weather Rev., 127, 2143-2159.

Dorman, C.E., T. Holt, D.P. Rogers, K. Edwards, 2000: Large-scale structure of the June-July 1996 Marine Boundary Layer along California and Oregon. Monthly Weather Rev., 128, 1632-1652.

\section{PUBLICATIONS}

Chao, Y., Z.Li, J. Kindle, J. Paduan, and F. Chavez, 2002: A high-resolution surface vector wind product for coastal oceans: blending satellite scatterometer measurements with regional mesoscale atmospheric model simulations. Geophys. Res. Letters. In Press.

Kindle, J.C., R. Hodur, S. deRada, J. Paduan, L.K. Rosenfeld, and F. Chavez, 2002: A COAMPSTM reanalysis for the eastern Pacific: properties of the diurnal sea breeze along the central California coast. Geophys. Res. Letters, In Press.

Pickett, M.H., J.D. Paduan, J.C. Kindle, and M.S. Cook, 2002: Near-shore wind stress curl off the U.S. West Coast derived from the COAMPS model. Abstract, $49^{\text {th }}$ Eastern Pacific Ocean Conference, Timberline Lodge, Oregon, 25-28 September.

Shulman, I., C.-R. Wu, J.K. Lewis, J.D. Paduan, L.K. Rosenfeld, J.D. Kindle, S.R. Ramp, and C.A. Collins, 2002: High resolution modeling and data assimilation in the Monterey Bay area. Cont. Shelf Res., 22, 1129-1151. 